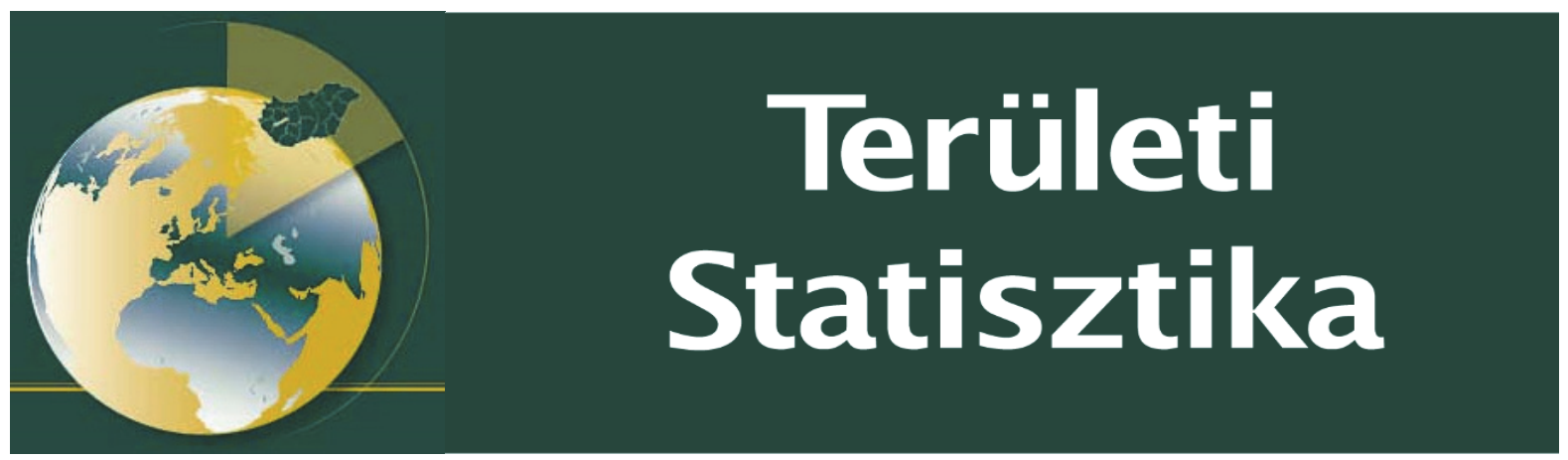

Közzététel: 2021. január 19.

A tanulmány címe:

A magyarországi városok telephelyi tényezőinek vállalati megítélése

Szerzők:

Koltai Zoltán - Filó Csilla

https://doi.org/10.15196/TS610104

Az alábbi feltételek érvényesek minden, a Központi Statisztikai Hivatal (a továbbiakban: KSH) Területi Statisztika c. folyóiratában (a továbbiakban: Folyóirat) megjelenó tanulmányra. Felhasználó a tanulmány, vagy annak részei felhasználásával egyidejüleg tudomásul veszi a jelen dokumentumban foglalt felhasználási feltételeket, és azokat magára nézve kötelező́nek fogadja el. Tudomásul veszi, hogy a jelen feltételek megszegéséböl eredö valamennyi kárért felelösséggel tartozik.

1) A jogszabályi tartalom kivételével a tanulmányok a szerzői jogról szóló 1999. évi LXXVI. törvény (Szjt.) szerint szerzői műnek minősülnek. A szerzői jog jogosultja a KSH.

2) A KSH földrajzi és időbeli korlátozás nélküli, nem kizárólagos, nem átadható, térítésmentes felhasználási jogot biztosít a Felhasználó részére a tanulmány vonatkozásában.

3) A felhasználási jog keretében a Felhasználó jogosult a tanulmány:

a) oktatási és kutatási célú felhasználására (nyilvánosságra hozatalára és továbbítására a

4. pontban foglalt kivétellel) a Folyóirat és a szerző(k) feltüntetésével;

b) tartalmáról összefoglaló készítésére az írott és az elektronikus médiában a Folyóirat

és a szerző $(\mathrm{k})$ feltüntetésével;

c) részletének idézésére - az átvevô mú jellege és célja által indokolt terjedelemben és az eredetihez híven - a forrás, valamint az ott megjelölt szerző(k) megnevezésével.

4) A Felhasználó nem jogosult a tanulmány továbbértékesítésére, haszonszerzési célú felhasználására. Ez a korlátozás nem érinti a tanulmány felhasználásával előállított, de az Szjt. szerint önálló szerzői műnek minősülő mú ilyen célú felhasználását.

5) A tanulmány átdolgozása, újra publikálása tilos.

6) A 3. a)-c.) pontban foglaltak alapján a Folyóiratot és a szerző(ke)t az alábbiak szerint kell feltüntetni:

„Forrás: Területi Statisztika c. folyóirat 61. évfolyam 1. számában megjelent, Koltai Zoltán - Filó Csilla által irt, $\boldsymbol{A}$ magyarországi városok telephelyi tényezöinek vállalati megítélése c. tanulmány"

7) A Folyóiratban megjelenő tanulmányok kutatói véleményeket tükröznek, amelyek nem esnek szükségképpen egybe a $\mathrm{KSH}$, vagy a szerzők által képviselt intézmények hivatalos álláspontjával. 


\section{A magyarországi városok telephelyi tényezőinek vállalati megítélése}

\section{Judgement of the location factors of Hungarian cities by businesses}

Koltai, Zoltán

Pécsi Tudományegyetem Kultúratudományi, Pedagógusképző

és Vidékfejlesztési Kar E-mail: koltai.zoltan@kpvk.pte.hu

Filó, Csilla

Pécsi Tudományegyetem Egészségtudományi Kar E-mail: csilla.filo@etk.pte.hu
A kutatás által vizsgált 2004 és 2017 közötti időszakban jelentősen átalakult a magyar gazdaság növekedését meghatározó térségek köre. Míg 2007 előtt a gazdasági növekedést elsődlegesen Budapest és vonzáskörzete határozta meg, addig az azt követő évtizedben ez a szerep áttevődött az erôteljes külföldi érdekeltségű feldolgozóiparral jellemezhető megyékre. Ennek hátterében az országosan javuló foglalkoztatás mellett a munkatermelékenység említett megyékben megfigyelhető kedvezó irányú folyamatai húzódtak meg, a központi régióban azonban ezzel éppen ellentétes tendenciák körvonalazódtak.

A tanulmány célja, hogy rétegzett kérdőíves megkeresések (magyarországi vállalkozások régiók, vállalatméret és szektorok szerinti megoszlása) alapján bemutassa a telephelyi tényezők magyarországi vállalati megítélését, jellemezze az értékelések időbeli változását. Vállalatokkal kapcsolatos, 2004/2005. évi kutatásukat a szerzők 2016/2017-ben megismételték. A kérdőívben három zárt, három nyitott és egy félig zárt, összesen hét kérdés keretében többek között a következő témakörökre kerestek választ: milyen szempontokat részesítenek előnyben a magyar vállalati szféra szereplői telephelyük megválasztásakor, mely magyarországi településeket, és miért tartanak sikeresnek a vállalatvezetők? A tanulmány a reprezentativitást biztosító ismérvek tükrében elemzi a vállalati válaszokat, majd ezt követően bemutatja a települések országos, regionális és ágazati sorrendjeit. A kutatás két külön elemzett témakörét (telephelyi tényezők érté-

Területi Statisztika, 2021, 61(1): 79-104; DOI: 10.15196/TS610104 
Kulcsszavak: sikeresség, telephelyi tényezők, településrangsor, vállalatok,

Magyarország kelése, ezek tükrében az egyes városok megitélése) a tanulmány komplex módon is vizsgálja. A szerzők választ keresnek továbbá arra a kérdésre is, hogy milyen okok állnak az egyes városok sikeres telephelyi megitélésének hátterében, valamint egymáshoz képest is értékelik a településeket. A kutatás eredményei hozzájárulhatnak az egyes települések komplex térségi tényezókínálatának megalapozásához, ami fejlesztéspolitikai szempontból azért különösen sürgető feladat, mivel vidéki nagyés középvárosaink egyelőre nem részei a globális városrendszernek.

In the 2004-2017 period, the focus of our research, namely the circle of regions determining the growth of the Hungarian economy went through a significant transition. Before 2007 Budapest and its hinterland were the main source of economic dynamism, in the following decade the counties with strong foreign-based manufacturing industry were much more responsible for the growth. In the background of this trend we find, in addition to the nationally improving employment conditions, the favourable processes in the improvement of the work productivity typical in these counties; meanwhile in the central region the opposite tendencies unfolded.

The aim of the paper is to demonstrate, using a layered questionnaire survey (breakdown of Hungarian enterprises by region, company size and sectors) the assessment of location factors by Hungarian enterprises and describe the change of evaluations over time. The research we had conducted with companies in 2004-2005 was repeated in 2016-2017. We focused in our questionnaire among others on the following issues, using three closed, three open and one semi-closed, altogether seven questions: what aspects do Hungarian 
Keywords: successfulness, location factors, ranking of settlements, businesses, businesses prefer when choosing their business location, which Hungarian cities are considered successful by company leaders and why? In the first part of the paper the responses by the companies are analysed, considering attributes allowing representativeness, this is followed by the ranking of settlements at national and regional scale and by economic sectors. The two separately analysed issues of the research (evaluation of location factors and assessment of the respective towns and cities in the light of the location factors) were comprehensively scrutinised by looking at the reasons behind the favourable assessment of some cities as business locations and the settlements were evaluated in comparison to each other, too. We believe that the findings may be a meaningful contribution to the foundation of the complex regional supply of factors in some settlements, which is an urgent task from development policy point of view because Hungarian large and mid-size cities are not integrated into the global urban Hungary system as of yet.

Beküldve: 2019. november 26.

Elfogadva: 2020. augusztus 31.

\section{Bevezetés}

A gazdasági tevékenységek gazdaságtörténeti korszakonként nagyon változatosan jelennek meg a térben. Az iparosítás előtti korokban a legfontosabb telepítési szempontok többnyire még agrárgazdasági jellegúek voltak, így a természeti erőforrások bősége, a felszíni és talajviszonyok, a víznyerés lehetőségei határozták meg a gazdasági szereplők földrajzi elhelyezkedését. A XIX. századi iparosítás folyamatában legnagyobb magyarázó ereje már a nyersanyaglelőhelyeknek, a tömeges szállításra alkalmas vízi utaknak és tengerpartoknak lett. A posztindusztriális társadalmakat elemezve kijelenthetjük, hogy a gazdasági folyamatok földrajzi megkötöttsége a korábbi időszakokhoz képest jelentősen csökkent. A deregulációs (liberalizációs) politika felerősödése, a versenyt korlátozó technikai és fizikai akadályok részleges vagy teljes felszámolása a korábbiaknál szabadabb piacválasztást, a több telephelyen

Területi Statisztika, 2021, 61(1): 79-104; DOI: 10.15196/TS610104 
múködő vállalati formák elterjedését, a transznacionális vállalatok piaci térnyerését hozta magával. Napjainkra egyre több vállalat kapcsolódhat be a nemzetközi piaci folyamatokba, melyek gyakran vállalaton belül, vállalati telephelyek között zajlanak. Ez a megnövekedett szabadság nemcsak a kibocsátott termékek és szolgáltatások, de a szükséges termelési tényezők áramlásában is testet ölt, általánossá téve a bárhonnan - bármit - bárhol - bárhová jelenséget (Lengyel 2003, 2010). A határok nélkülivé váló gazdasági folyamatokat tovább erősíti a technológiai fejlődés, a modern információs és kommunikációs technikák megnövekedett gazdasági szerepe, amely a távolságból eredő költségek és időigény jelentős mérséklődésével másodrendűvé tette utóbbiakat a működési helyszín megválasztásában. A gazdaság szerkezeti átalakulása, a szolgáltatások és a tudásalapú gazdaság térnyerése, az iparvállalatok gyártási folyamatainak részekre bontása tovább bővíti a nemzetközi gazdasági folyamatokba bekapcsolódó potenciális helyszínek körét, felerősítve azok differenciált jellemzőit. Természetesen e folyamatok konfliktusokhoz is vezetnek, elég csak a munkahelyek térbeli elmozdulására, a lokális piacokon megerősödő konkurenciára, a globálisan korlátozottan rendelkezésre álló erőforrásokért folytatott versengésre gondolnunk (Nagy 2010). A nemzetállamok szerepvesztésével a közigazgatás korábban elképzelhetetlen mértékú decentralizációja, ezzel párhuzamosan a regionális és települési autonómia növekedése vált jellemzővé. Magyarország esetében ezt a folyamatot tovább erősítette a centralizált társadalomirányítás helyébe lépő piacgazdasági modell, amely egyrészt tág teret nyitott a térségi kapcsolatrendszerek fejlődésének, felértékelte az ország minden pontját, megnyitva annak lehetőségét, hogy a lokális potenciál országossá vagy akár nemzetközivé bővülhessen (Nemes Nagy 1998).

Másrészt mindezzel párhuzamosan a társadalmi és gazdasági tevékenységek térbeli elhelyezkedésének magyarázatát kutató telephelyelméletek is lényegesen átalakultak. A hagyományos telephelyelméletek (ide sorolhatjuk Johann von Thünen mezőgazdasági területhasználattal kapcsolatos elméletét, Alfred Weber ipari telephelyelméletét, August Lösch térbeli versennyel és egyensúllyal kapcsolatos vizsgálatait) még alapvetően a mezőgazdaság és a feldolgozóipar térbeli jellemzőit modellezték, központi kategóriaként szerepeltetve a költségek minimalizálását, a gazdasági profit megszerzését (Rechnitzer 1994, Varga 2002, Lengyel-Rechnitzer 2004, Enyedi 2012). A szolgáltatások megnövekedett szerepével, az egyedi termékek iránti fogyasztói kereslet emelkedésével, a vállalati hálózatok, klaszterek, valamint a gazdaságon kívüli, kevésbé vagy egyáltalán nem számszerűsíthető externáliák térnyerésével a korábbiaktól már lényegesen különböző tényezôk is befolyásolják a helyszínválasztást. A nem vagy nem teljeskörűen megmagyarázott empirikus problémák tisztázásának szándéka új kereskedelmi elméletek megszületéséhez vezetett, melyek központi fogalomként használják a külső (iparági) és a belső méretgazdaságosságot, a termékdifferenciálást és -életciklust, a piacszegmentációt, az árdiszkriminációt és a nem tökéletes versenyt (Krugman 1993, 1994, 1998, Storper

Területi Statisztika, 2021, 61(1): 79-104; DOI: 10.15196/TS610104 
2000, Scott et al. 2001, Scott-Storper 2003, Caniels-Romijn 2006). A vállalati stratégiai közgazdaságtan (kompetitív előnyök elmélete) visszavezethetô Michael Porter (1996, 1999, 2000) munkásságára. Mely szerint a globális vállalati verseny forrásai földrajzi koncentrációt mutatnak, a verseny tulajdonképpen a lokális előnyöket biztosítani képes térségek között értelmezhető. Említett szerző empirikus kutatásaira támaszkodva úgy véli, hogy a térségek versenye alapvetően a helyben múködő (letelepedni szándékozó) vállalatok sikeressé válásához való hozzájárulást jelenti, az ezt elósegítő üzleti környezet megteremtése által. Porter épít a pozitív lokális extern hatásokra, melyeket mint agglomerációs előnyöket a versenyben való sikeres helytállás alapfeltételeként határoz meg. Végül újabb keletû magyarázatként érintenünk kell a területitőke-elméleteket is (Camagni 2008, 2009, Jóna-Hajnal 2014, Tóth 2014). Megközelítésük a humán, a kapcsolati és a társadalmi tóke szerepének elótérbe helyezésével még inkább kiemeli a helyi szereplők aktív részvételének jelentőségét az endogén térségfejlesztési folyamatokban.

Kutatási célunk, hogy hozzájáruljunk az egyes települések komplex térségi tényezőkínálatának megalapozásához, ami fejlesztéspolitikai szempontból azért különösen aktuális információ az döntéshozók számára, mert vidéki városaink funkcionálisan gyengék, elmaradnak az elégséges méretgazdasági kritériumoktól és egyelőre nem részei a globális városrendszernek sem.

\section{A telephelyi tényezők átértékelödési folyamata Magyarországon}

Az 1980-as évek végéig Magyarországon nem volt telephelyi adottságokon alapuló valódi versenyhelyzet. A településhálózat fejlődése jellemzően központi döntésektől függött, gondoljunk például az állami ipartelepítésre, az ehhez szervesen kapcsolódó lakásépítésekre, a jóléti rendszerek, intézményhálózatok és az infrastruktúra fejlesztésére. A települések vezetőinek személyes kapcsolatai, a már akkor is létező lobbitevékenységet leszámítva a helyi, endogén adottságok és erőforrások, a lokális társadalom nyújtotta kedvezőbb feltételek alig játszottak szerepet a gazdasági szereplők telephelyválasztásában. A felülről irányított fejlesztési folyamatokat áthatotta az intézménytelepítés „modellszerû” gyakorlata, a szolgáltatók monopolhelyzete, a közigazgatási szerepkör és besorolás elsődlegessége. Kedvező pozícióik következtében a megye- és járási székhelyeken sorra alakultak a lakosság mindennapi életkörülményeit alapjaiban meghatározó intézmények. A társadalmi-foglalkozási hierarchiában való elörelépés individuális szándéka előbb-utóbb szükségessé tette a településhierarchiában való elmozdulást is (Kőszegfalvi 2020), ami magával hozta az ingázást és a migrációt, érintve ezzel a népesedési folyamatokat és helyi szinten a társadalmi rétegződést is. A korabeli településállományt kevés sajátos profilú város, ehelyett egy meglehetôsen homogén, koncentráltan fejlődő hazai városállomány jellemezte. Mivel a különbségek elsősorban a településhierarchia mentén jelentkeztek, mindez egy mozaikszerú térszerkezet kialakulásában öltött testet. Az említett

Területi Statisztika, 2021, 61(1): 79-104; DOI: 10.15196/TS610104 
korszakot elemző nemzetközi egyenlőtlenségvizsgálatok alátámasztják, hogy a közép-kelet-európai szocialista országok a hasonló fejlettségú piacgazdaságokhoz képest regionálisan kiegyenlítettebb térszerkezetúek voltak, kisebb mértékú gazdasági fejlettségbeli és jövedelmi különbségekkel (Nemes Nagy 1996, Nemes NagyTagai 2009, Lukács 2020). A harmonikus térszerkezet mögött meghúzódó túltámogatott termelőágazatok, a bér- és jövedelemviszonyokat átható nivelláció viszont alapjaiban állt szemben a piacgazdaságokat jellemző növekvő tercierizációval és a jelentős mértékú infrastruktúrafejlesztési igénnyel. Amellett, hogy a nélkülözhetetlen fejlesztésekhez hiányoztak a szükséges források, a gazdaság még képtelennek is mutatkozott egy erôteljes nyitásra a korszerú ipari technológiák és gazdaságszerkezet irányába. Emiatt aztán nem is derülhetett ki, hogy valójában mely régiók és települések lettek volna alkalmasak a modern gazdaság fogadására és múködtetésére, a piaci alapú nemzetközi kooperációkban történő részvételre (Nemes Nagy-Ruttkay 1993, Nemes Nagy 1999).

A magyar települések telephelyi sikerességét napjainkra elsősorban belső adottságaik határozzák meg. A településhierarchiában elfoglalt pozíció, a közigazgatási szerepkör mellett (de nem helyett) meghatározó faktorrá a gazdasági adottságok és a jövedelemszerzési lehetőségek váltak. A közszolgáltatásokkal szemben megerősödött a piaci alapú tevékenységek, fő́ként a modern üzleti szolgáltatások magyarázó ereje, ami a szolgáltató vállalkozások rugalmasabb telephelyválasztásán keresztül még több település számára tette lehetôvé a gazdasági folyamatokba történő aktív bekapcsolódást. Az előzőekkel szoros összefüggésben felértékelődött a települések földrajzi elhelyezkedése, továbbá megközelíthetőségük, infrastrukturális ellátottságuk, történelmi-kulturális adottságaik, humán erőforrásaik képzettsége, az innovációt hordozó intézmények megléte, környezeti állapotuk és nem utolsósorban a helyi fejlesztéspolitika aktivitása (Enyedi 1996, Rechnitzer 1998, LengyelRechnitzer 2000). Úgy is magyarázhatnánk, hogy a rendszerváltozással párosuló lehetőségeket azokban a térségekben tudták a legjobban kihasználni, ahol a képzett népesség gazdasági előnnyé tudta alakítani felhalmozott szellemi-kulturális és kapcsolati-információs tőkéjét. Amennyiben ezek a tényezők egy térségben viszonylag kedvező infrastrukturális adottságokkal párosultak, szinte biztos volt a kedvező folyamatok beindulása (Szakálné Kanó et al. 2017, Pénzes et al. 2018, Tagai et al. 2018, Rechnitzer 2019, Rechnitzer et al. 2019). A privatizáción keresztül történő tôkebevonást az állami vagyon mennyiségének és minőségének földrajzilag nagyon eltérő indulófeltételei és örökölt gazdasági kultúrája határozta meg. A zöldmezős beruházások esetében a nyugati piacokhoz (és Budapesthez) való közelség, a kedvező közlekedési és kommunikációs infrastruktúra, a képzett és olcsó munkaerő megléte, nem utolsósorban a helyi és központi gazdaságpolitika támogatása volt meghatározó befolyással. A nemzetközi tóke tömegméretú megjelenése és annak a korábbiaktól gyökeresen eltérő telephelyválasztási szempontjai szintén hozzájárultak a települések közötti verseny élénküléséhez (Barta 2000,

Területi Statisztika, 2021, 61(1): 79-104; DOI: 10.15196/TS610104 
Hrubi 2000). A verseny regionális dimenziója megélénkült, ami egyértelmúen a regionális hovatartozás versenyképességet befolyásoló szerepének erősödését jelzi. Mivel a gazdasági szereplők telephelyválasztása piacgazdasági törvényeket követ, egyértelmúen megmutatkoztak azok a települési különbségek, melyeket az állami tulajdonú gazdaság korábbi, nem piaci jellegű döntései még sikeresen elfedtek (Enyedi 1993, Bakos et al. 2011). A versenyképesség továbbra is erős hierarchikus meghatározottsága okán kijelenthető, hogy közép- és nagyvárosaink vonzása részben ellensúlyozhatja kedvezőtlen földrajzi fekvésüket. Bár a kis- és középvárosok sem humán erőforrásaikat, sem intézményi adottságaikat tekintve nem rendelkeznek nagyvárosi feltételekkel, azonban a tartós gazdasági növekedést mutató régiókban egy hálózat részeként ezek is fejlesztőleg hathatnak a környezetükre (Harcsa 2015, Pirisi et al. 2016).

De vajon mit gondolnak errôl a leginkább érintett szereplők, maguk a vállalkozások? Mit tekintenek saját környezetük legfőbb előnyeinek és hátrányainak? Ezekre a kérdésekre kerestünk választ kérdőíves vizsgálatunkban.

\section{Kutatási eredmények}

Vállalatokkal kapcsolatos, 2004/2005-ben lefolytatott kutatásunkat 2016/2017-ben ismételtük meg (Koltai 2006, 2007), amikor is rétegzett kérdőíves megkeresésünkre (magyarországi vállalkozások régiók, vállalatméret és szektorok szerinti megoszlása) ismét ezer vállalkozó, vállalatvezető adott választ kérdéseinkre. A vállalkozások területi megoszlását alapul véve, a megkérdezettek $40 \%$ feletti arányban KözépMagyarországról, a többi régióból pedig 8-12\% közötti arányban kerültek ki. Vizsgálatunk során valamennyi magyarországi megyéből kaptunk válaszokat. Vállalatméret szerint a mikro- és kisvállalatok 96\% feletti arányban szerepeltek mintánkban. A szolgáltató ágazat képviselői 79,0, az iparvállalatok 17,5, az agrárvállalkozások 3,5\%-os részarányt képviseltek. A személyes megkérdezéseknek köszönhetően a kitöltött kérdőívek szinte kivétel nélkül értékelésre alkalmasak voltak. Kérdőívünkben három zárt, három nyitott és egy félig zárt, összesen hét kérdés keretében az következő témakörökben kerestünk választ:

- Milyen szempontokat részesítenek előnyben a magyar vállalati szféra szereplői telephelyük megválasztásakor?

- Melyik magyarországi településeket és miért tartják sikeresnek a vállalatvezetők?

- Melyek azok a települések, melyeket valódi gazdasági központoknak tekintenek?

- Milyen belföldi és nemzetközi mobilitási hajlandóság jellemzi a magyar vállalkozásokat?

- A különböző településtípusokon melyek a vállalati múködés előnyei, illetve hátrányai?

Területi Statisztika, 2021, 61(1): 79-104; DOI: 10.15196/TS610104 
Jelen tanulmányban a telephelyi tényezőkkel kapcsolatos kutatási eredményeink megismertetésére vállalkozunk. A tanulmány további részeiben részletesen vizsgált hipotéziseink a következőkben foglalhatók össze:

- a 2004/2005. évi kutatási eredményeink alapján magasra értékelt telephelyi tényezők (regionális elérhetőség, felvevőpiac) 2016/2017-ben is elsődlegesek,

- az innovációs kultúra nagyvállalati felértékelődése, valamint a vállalatméret növekedésével párhuzamosan a felvevőpiac és a környezeti minőség magyarázó erejének csökkenése,

- a gazdasági szerkezet, az innovációs kultúra, a regionális elérhetőség, az üzleti szolgáltatások és a felvevôpiac telephelyi tényezők megítélésének országrészek közötti jelentős különbségei,

- míg a regionális elérhetőség a szolgáltató szektor számára kevésbé lényeges, addig a felvevőpiacé fontosabb az ipari és agrárvállalkozási szektorhoz képest,

- a sikeres telephelyek élmezőnyében nagyvárosok, régió- és megyeközpontok (Páthy 2017) találhatók, és a regionális listák második felében az érintett megyék közép- és kisvárosai is megjelennek.

\section{A telephelyi tényezők vállalati megítélése}

A telephelyválasztást befolyásoló tényezők összegyújtésével egy meglehetősen terjedelmes listát kapunk. Ide sorolhatók többek között a szállítási és egyéb infrastrukturális lehetôségek, a természeti környezet adottságai, a piacok (fogyasztói kereslet), a legfontosabb inputok, a társadalmi-kulturális környezet, az externáliák és a központi, helyi kormányzati politika egyaránt. Vagyis a telephelyi tényezők között találunk olyanokat, amelyek az inputok beszerzéséhez, valamint az outputok piacra juttatásához kapcsolódnak, s végül megjelennek közöttük extern hatások is. Mindez alátámasztja, hogy a telephelyválasztás meglehetôsen komplex döntési probléma és mindig különböző tényezők kombinációin alapul (Kiss 2010, Józsa 2017).

Az első kérdés keretében arra kerestünk választ, hogy az általunk kiválasztott telephelyi tényezoók mennyire fontosak a múködési helyszín kijelölésekor. 2016/2017. évi kutatásunkban a következő tizenkét tényező értékelésére kértük a válaszadókat, ötfokozatú skálát alkalmazva:

1. A település gazdasági szerkezete (ágazati szerkezet, kapcsolódó iparágak, beszállítói kapcsolatok, háttéripar fejlettsége).

2. A település innovációs kultúrája, szellemi tôkepotenciálja (kutatás-fejlesztési kapacitások, felsőfokú oktatási intézmények, kutatóintézetek léte).

3. A regionális elérhetôség, a település földrajzi fekvése (közlekedési infrastruktúra, Budapest megközelíthetősége).

4. A múködéssel kapcsolatos költségek (munkabérek, adók, adókedvezmények).

5. A helyi önkormányzat aktivitása, településpolitikája (befektetésösztönzés, városmarketing, ügyintézési menet, konfliktuskezelési mód).

Területi Statisztika, 2021, 61(1): 79-104; DOI: 10.15196/TS610104 
6. A település környezeti minősége (lakóhelyi adottságok, természeti és épített környezet, szabadidős, egészségügyi és oktatási intézmények).

7. A település közintézményekkel való ellátottsága (közszolgáltatások, hivatalok múködése).

8. A település üzleti szolgáltatásai (bankhálózat, ipari park, vállalkozásfejlesztési iroda múködése).

9. A munkaerô felkészültsége és hatékonysága (iskolai végzettség, nyelvismeret, munkatermelékenység, munkaerőpiaci adatok).

10. A település mint felvevőpiac (piacméret, fogyasztói potenciál, vonzáskörzet jelleg).

11. A település demográfiai és társadalmi adottságai (korszerkezet, migrációs folyamatok, népsűrüség).

12. A település nemzetközi kapcsolatrendszere (külföldi érdekeltségú vállalkozások és beruházások, testvérvárosi kapcsolatok, turizmus).

2004/2005. évi kutatásunk tényezőrendszerét 2016/2017-ben a 11. és a 12. tényezôvel egészítettük ki.

2004/2005. évi kutatásunk válaszadói első helyre a regionális elérhetőséget sorolták, amit valamivel lemaradva a felvevôpiac követett (Koltai 2006, 2007, 2014). A következő, közepesre értékelt tényezőcsoportot az üzleti szolgáltatások, a gazdasági szerkezet, a múködési költségek, a munkaerő és a közintézmények alkották. Sorrendben a környezeti minőség és településpolitika következett, a legalacsonyabb pontértéket pedig az innovációs kultúra kapta. (Érdekes párhuzamosságok mutatkoznak Kozma [1998] hazai ipari közép- és kisvállalkozások telepítőtényezőinek fontosságát vizsgáló kutatásával, melyben a munkaerő minősége mellett szintén a közlekedési, kommunikációs infrastruktúra és a fogyasztópiac nagysága került az élre, a sort pedig a tudományos intézetek, egyetemek jelenléte zárta. Nagy és Nagy [2008] az üzleti szolgáltatások tudás- és információáramlásban betöltött szerepét hangsúlyozzák gazdasági centrumokat elemző kutatásukban. A telephelyválasztás okait kutatva Lux [2013] kiemeli a helyi kötődés [termelési hagyományok, kapcsolatrendszerek] magyarázó erejének elsődlegességét, amit a munkaerő kvantitatív és kvalitatív tényezői, a városi környezet és a közlekedési infrastruktúra követnek.)

Első hipotézisként a 2004/2005-ben magasra értékelt tényezők (regionális elérhetőség, felvevőpiac) további elsődlegességét vártuk, míg az újonnan bevezetettek közül a nemzetközi kapcsolatok fontosságát feltételeztük. Utóbbi telephelyi tényező kiemelten a nemzetközi piaci kapcsolatrendszereket múködtető közép- és nagyvállalatok körében számít meghatározónak.

2016/2017. évi kutatásunk eredményei alapján a rangsor első helyére már a múködési költségek kerültek, amit a regionális elérhetőség és a felvevőpiac követ (1. ábra). A következő csoportot a munkaerő vezeti, megelőzve a gazdasági szerkezetet, az üzleti szolgáltatásokat, a településpolitikát, a környezeti minőséget és a közintézményeket. Továbbra is a legalacsonyabbra értékelt tényezók között szerepel az in-

Területi Statisztika, 2021, 61(1): 79-104; DOI: 10.15196/TS610104 
novációs kultúra, ahogy szintén a lista végén találjuk mindkét új tényezőnket, a demográfia-társadalmat és a nemzetközi kapcsolatokat.

Az 1-10. tényező kivétel nélkül magasabb pontértéket kapott a 2004/2005. évihez képest. Közülük az átlagosnál nagyobb mértékben nőtt a településpolitika, a múködési költségek, a munkaerő, az innovációs kultúra és a környezeti minőség magyarázó ereje. Megállapítható, hogy a magyar vállalkozások egyrészt költségérzékenyebbé váltak 2004/2005 és 2016/2017 között, másrészt fontosabbá vált számukra a felkészült és hatékony munkaerő megléte vagy éppen annak hiánya. Ha figyelembe vesszük a munkaképes korú népesség (15-64 évesek) létszámának országos csökkenését, mely alól egyedül Közép-Magyarország jelent kivételt a vizsgált időszakban, kijelenthető, hogy a kvalifikált munkaerő megszerzése egyre nagyobb kihívások elé állítja a magyar vállalkozásokat (Lengyel-Varga 2018, Alpek et al. 2018). Az innovációs kultúra felértékelődését erősíti az a tény, hogy a két adatfelvétel között kismértékú kiegyenlítődés figyelhető meg az egy lakosra jutó K+F-beruházások megyei értékeiben. Mindez elsősorban Közép-Magyarország hátrányára és a jelentősebb külföldi érdekeltségű feldolgozóiparral rendelkező megyék előnyére történt. Rechnitzer (2019) a megyei jogú városok fejlesztési stratégiáit elemezve szintén kiemeli az innováció és a szellemi erőforrások elmúlt évekbeli felértékelődését.

\section{A telephelyi tényezők fontossági sorrendje} a magyar vállalatok megkérdezése alapján

Ranking of location factors, based on the responses of the surveyed Hungarian businesses

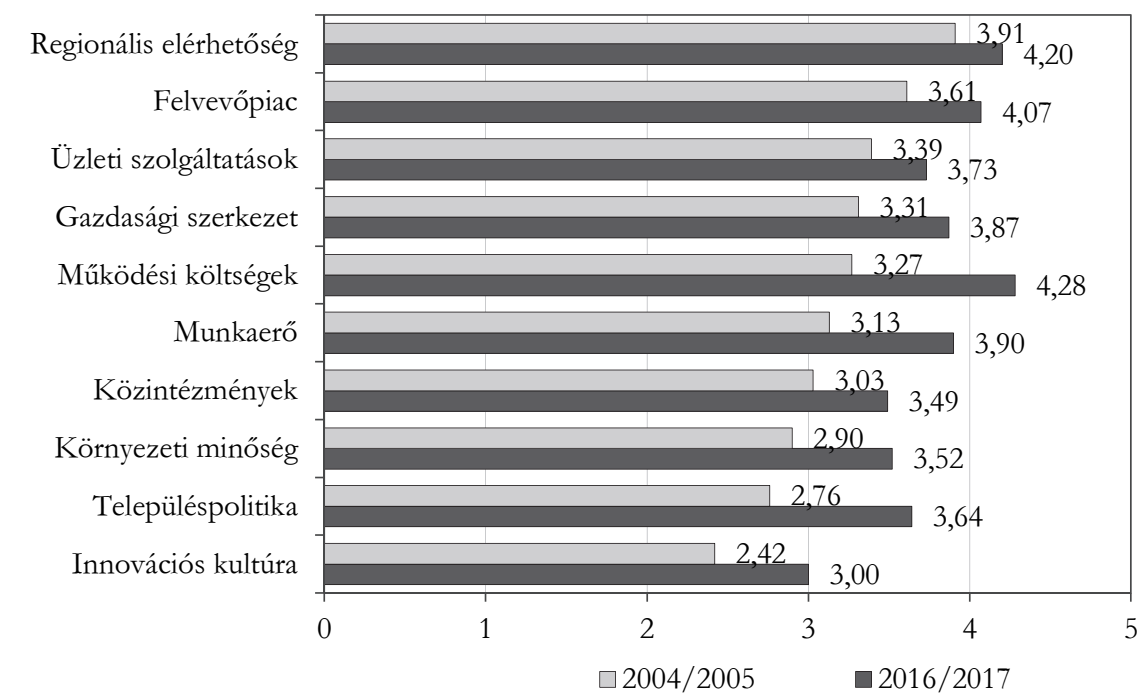

Megjegyzés: a megkérdezett vállalkozók és vállalatvezetők az egyes telephelyi tényezőket ötfokozatú skálán értékelték.

Forrás: a szerzők 2004/2005. és 2016/2017. évi kutatása.

Területi Statisztika, 2021, 61(1): 79-104; DOI: 10.15196/TS610104 
Eredményeink tükrében első hipotézisünk csak részlegesen teljesült, egyrészt a múködési költségek nem várt módon a rangsor élére kerültek, másrészt a nemzetközi kapcsolatokra adott pontérték elmaradt az elózetes várakozásunktól.

Két felmérésünk eredményeit abból a szempontból is összehasonlítottuk, hogy a változók közötti kapcsolatrendszer hasonló faktorstruktúrát mutat-e. A struktúra világos kimutatása érdekében varimax rotációt alkalmaztunk. A szoros kapcsolatot 0,5 felett határoztuk meg, a tényezők 2004/2005-ben öt faktorba voltak besorolhatók (1. táblázat).

1. táblázat

\section{A telephelyi tényezők faktorai a magyar vállalatok megkérdezése alapján,} $2004 / 2005$

Factors of location considerations, based on the responses of surveyed Hungarian businesses, 2004/2005

\begin{tabular}{|c|c|c|c|c|c|}
\hline Tényező & $\begin{array}{l}\text { Üzleti- } \\
\text { környezet- } \\
\text { faktor }\end{array}$ & $\begin{array}{c}\text { Gazdasági- } \\
\text { fejlettség-faktor }\end{array}$ & $\begin{array}{l}\text { Szabályozási- } \\
\text { támogatási } \\
\text { keretek faktora }\end{array}$ & Piacfaktor & $\begin{array}{c}\text { Lakókörnyezet- } \\
\text { faktor }\end{array}$ \\
\hline Gazdasági szerkezet & & 0,766 & & & \\
\hline Innovációs kultúra & & 0,762 & & & \\
\hline Regionális elérhetőség & & & & 0,689 & \\
\hline Működési költségek & & & 0,854 & & \\
\hline Településpolitika & & & 0,747 & & \\
\hline Környezeti minőség & & & & & 0,907 \\
\hline Közintézmények & 0,829 & & & & \\
\hline Üzleti szolgáltatások & 0,811 & & & & \\
\hline Munkaerő & & 0,556 & & & \\
\hline Felvevőpiac & & & & 0,816 & \\
\hline
\end{tabular}

Forrás: a szerzők 2004/2005. évi kutatása.

A figyelembe vett változók közötti szoros korreláció alapján azok alkalmasnak mutatkoztak újabb faktorelemzésre, melynek során azok információtartalmának 76\%-át őriztük meg. Az optimális táblázatot ezúttal négy iterációt követően kaptuk meg (2. táblázat):

1. üzletikörnyezet-faktor (településpolitika, környezeti minőség, közintézmények),

2. gazdaságifejlettség-faktor (gazdasági szerkezet, innovációs kultúra, regionális elérhetőség, munkaerő, nemzetközi kapcsolatok),

3. piacfaktor (felvevőpiac, demográfia-társadalom),

4. költségfaktor (működési költségek).

Területi Statisztika, 2021, 61(1): 79-104; DOI: 10.15196/TS610104 


\section{A telephelyi tényezők faktorai a magyar vállalatok megkérdezése alapján,}

$2016 / 2017$

Factors of location considerations, based on the responses of surveyed Hungarian businesses, 2016/2017

\begin{tabular}{l|c|c|c|c}
\hline \multicolumn{1}{c|}{ Tényező } & $\begin{array}{c}\text { Üzletikörnyezet- } \\
\text { faktor }\end{array}$ & $\begin{array}{c}\text { Gazdasági- } \\
\text { fejlettség-faktor }\end{array}$ & Piacfaktor & Költségfaktor \\
\hline Gazdasági szerkezet & & 0,670 & \\
Innovációs kultúra & 0,746 & & \\
Regionális elérhetőség & 0,551 & \\
Múködési költségek & 0,733 & & \\
Településpolitika & 0,714 & & \\
Környezeti minőség & 0,681 & 0,446 & \\
Közintézmények & & 0,544 & \\
Üzleti szolgáltatások & & & \\
Munkaerő & & 0,529 & 0,749 & \\
Felvevőpiac & & & \\
Demográfia-társadalom & & & \\
Nemzetközi kapcsolatok & & &
\end{tabular}

Forrás: a szerzők 2016/2017. évi kutatása.

A két felvétel faktorstruktúráját összehasonlítva megállapíthatjuk, hogy a regionális elérhetôség tényező a piacfaktorból átkerült a gazdaságifejlettség-faktorba, ahol megjelenik az új tényezők egyike, a nemzetközi kapcsolatok is. (Az üzleti szolgáltatások tényező szintén a gazdaságifejlettség-faktorral mutat legszorosabb kapcsolatot, de annak szorossága elmarad a 0,5-ös szinttől.) A 2004/2005. évi üzletikörnyezetfaktor 2016/2017-ben kibővül a településpolitika és a környezeti minőség tényezőkkel, míg a másik új tényező (a demográfia-társadalom) a piacfaktorban szerepel.

Érdekes tendenciák figyelhetôk meg akkor, amikor vállalatméret szerint különkülön is megvizsgáljuk az egyes tényezők pontértékeit. Második hipotézisként az innovációs kultúra nagyvállalati körben történő felértékelődését fogalmaztuk meg, ahogy arra is számítottunk, hogy a vállalatméret növekedésével párhuzamosan veszít jelentőségéből a felvevőpiac és a környezeti minőség magyarázó ereje.

2004/2005. évi kutatásunkban méretkategóriától függetlenül a legfontosabb telepítési tényezőnek a regionális elérhetőség számított. (2004/2005-ben valamennyi vállalatméretnél ez szerepelt az első helyen, és a legmagasabb pontértéket [4,21] a nagyvállalatok adták erre a tényezőre.) Ez 2016/2017-ben annyiban módosult, hogy a mikro-, kis- és nagyvállalatok jelenleg már a múködési költségeket tartják a legfontosabb tényezőnek, a középvállalkozások pedig a munkaerőt, utóbbi egyben a teljes adatfelvétel maximumértéke $(4,48)$ is. 
A mikrovállalkozások válaszai, mintánkban szereplő magas arányuk miatt egybeestek a teljes minta válaszaival, ahogy a kisvállalatok (10-49 fó) esetében sem volt számottevő különbség. (A teljes mintában a legalacsonyabb pontértéket $(2,9)$ a mikrovállalatok esetében mértük, mellyel a nemzetközi kapcsolatokat jellemezték.) Ezzel szemben a középvállalatok (50-249 fö) és főleg a nagyvállalatok (250 fő felett) válaszai lényegesen különböznek egymástól. A középvállalatoknál, ahogy azt korábban már jeleztük, a munkaerő kapta a legmagasabb pontértéket, amit szintén jelentősen felértékelve a múködési költségek, a regionális elérhetőség és a gazdasági szerkezet követnek. Lényegesebb tényezővé vált középvállalati szinten az innovációs kultúra, ellenben jóval hátrébb került a rangsorban a felvevőpiac. A nagyvállalati válaszok alapján (2. ábra) a még magasabbra értékelt múködési költségeket a regionális elérhetôség és a munkaerő követi, ahogy esetükben szintén fontosabbá vált a gazdasági szerkezet és az innovációs kultúra is. Várakozásainknak megfelelően a felvevőpiac és a környezeti minőség veszített fontosságából, ami továbbra is azt jelzi, hogy a nagyvállalatok elsősorban nem a helyi piacra termelnek, és esetükben a múködési helyszín sokkal kevésbé lakóhelyi, mint inkább telephelyi szempontokat szolgál. (Hasonló eredményekről számoltak be Kozma [1998] a többnyire ipari tevékenységet folytató hazai kis- és középvállalkozások felvevőpiacainak vizsgálatában, valamint Kovács és szerzôtársai [2017] a feldolgozóipari középvállalatok részletes elemzésében.) Második hipotézisünk ezzel egyértelmúen megerősitést kapott.

\section{A telephelyi tényezők fontossági sorrendje \\ a magyar nagyvállalatok megkérdezése alapján, 2016/2017}

Ranking of location factors, based on the responses of surveyed Hungarian large businesses, 2016/2017

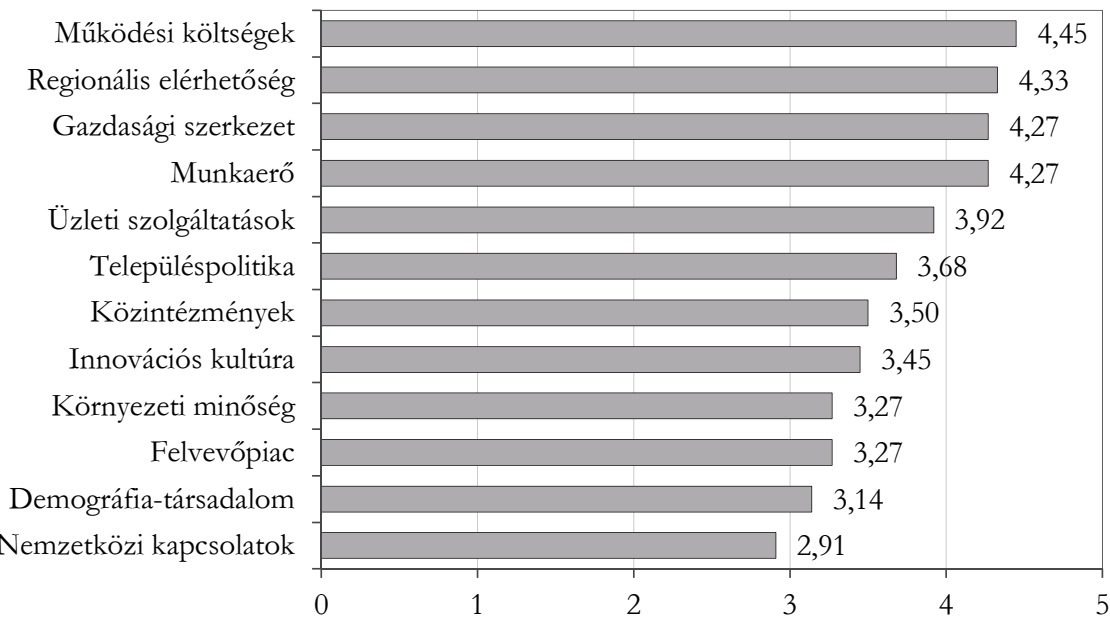

Megjegyzés: a megkérdezett vállalkozók és vállalatvezetők az egyes telephelyi tényezőket ötfokozatú skálán értékelték.

Forrás: a szerzők 2016/2017. évi kutatása.

Területi Statisztika, 2021, 61(1): 79-104; DOI: 10.15196/TS610104 
A vállalatok régiók szerinti elhelyezkedését alapul véve szintén feltételeztünk öszszefüggéseket. 2004/2005. évi kutatásunk során a gazdasági szerkezet és az innovációs kultúra a három dunántúli régió vállalataitól kapott magasabb pontértéket, mindkét tényezőé Dél-Dunántúlon volt a legalacsonyabb. Közép-Magyarország pontértékei ekkor valamivel elmaradtak az átlagtól. A regionális elérhetőség szempontjából már egyértelmủen kettéváltak az ország nyugati részének vállalatai, hiszen e tényező Dél-Dunántúlon ugyanúgy átlag alatti pontértéket kapott, mint ÉszakMagyarországon vagy Dél-Alföldön. A településpolitikát, valamint a munkaerôt Észak-Alföldön, a környezeti minőséget pedig Nyugat-Dunántúlon értékelték legtöbbre a megkérdezett vállalatok. Ez utóbbi adat Közép-Magyarországon volt a legalacsonyabb. Az üzleti szolgáltatásokra és a felvevőpiacra a három gazdaságilag fejlettebb régió (Közép-Magyarország, Nyugat- és Közép-Dunántúl) válaszadói adtak magasabb pontértéket, melyekhez szintén Észak-Alföld pontértékei álltak közelebb. (2004/2005-ben a legalacsonyabb pontértéket [2,21] a dél-alföldi vállalatok adták az innovációs kultúrára, míg a legmagasabbat $[4,12]$ a középmagyarországi vállalatok a regionális elérhetőségre.)

Mivel 2004/2005. évi kutatási eredményeink alapján egyértelmúen kirajzolódtak bizonyos regionális különbségek az egyes tényezők szerint, továbbra is számítottunk ezek megjelenésére. Harmadik hipotézisként elsősorban a gazdasági szerkezet, az innovációs kultúra, a regionális elérhetőség, az üzleti szolgáltatások és a felvevőpiac tényezők megítélésében 2016/2017-ben az országrészek között vártunk jelentős különbségeket. Az új tényezők közül a nemzetközi kapcsolatokat szintén ebbe a csoportba soroltuk.

- Közép-Magyarországon országos összehasonlításban ismét kimagasló pontértéket adtak a válaszadók a regionális elérhetőségre $(4,44)$, ellenben alacsonyra értékelték a településpolitikát $(3,39)$. E régió vállalkozásai a múködési költségek és a munkaerő tényezők esetében növelték leginkább a 2004/2005. évi pontértéket.

- Közép-Dunántúl vállalatai a gazdasági szerkezetet $(4,1)$ és az innovációs kultúrát $(3,09)$ értékelték országos összevetésben a legmagasabbra, legnagyobb mértékben pedig a településpolitikára adott pontértékek növekedtek.

- A nyugat-dunántúli vállalkozások a múködési költségekre (4,5) és a településpolitikára $(3,99)$ adtak kimagasló pontértéket, amely mögött mindkét tényező 40\%-ot meghaladó pontérték-növekedése húzódik meg a két felvétel között.

- Dél-Dunántúlon találjuk a legmagasabb pontértéket a nemzetközi kapcsolatok esetében $(3,19)$, szintén kiemelkedő a múködési költségeké $(4,41)$, ezzel szemben a helyi válaszadók jelentősen alulértékelték az üzleti szolgáltatásokat $(3,43)$. Hasonlóan Nyugat-Dunántúlhoz, itt is a múködési költségekre és a településpolitikára adott pontértékek emelkedtek a legnagyobb mértékben.

- Észak-Magyarország válaszadói több telephelyi tényező esetében a legmagasabb országos pontértékeket adták, így a munkaerőre $(4,11)$, a demográfia-

Területi Statisztika, 2021, 61(1): 79-104; DOI: 10.15196/TS610104 
társadalomra $(3,68)$ és a településpolitikára $(4,05)$ is. Nem véletlen, hogy ezek a pontértékek emelkedtek legnagyobb mértékben.

- Az észak-alföldi vállalatok sokkal inkább az egyes tényezők alacsonyra értékelésével tűnnek ki. Országos összevetésben a legalacsonyabb pontértékeket náluk találjuk a gazdasági szerkezet $(3,64)$, az innovációs kultúra $(2,8)$, a múködési költségek $(3,99)$ és a települések nemzetközi kapcsolatok $(2,58)$ esetében. Ellenpéldát a felvevőpiac $(4,4)$ és az üzleti szolgáltatások $(3,83)$ jelentenek, melyeket jóval fontosabbnak tartanak a gazdaság helyi szereplői.

- Dél-Alföldön országos összehasonlításban is magasnak számítanak a gazdasági szerkezetre $(4,0)$ és a nemzetközi kapcsolatokra $(3,1)$ adott pontértékek, míg ebben a régióban értékelték a vállalatok legalacsonyabbra a regionális elérhetőséget $(3,83)$. Itt is kiemelhető a településpolitikára, a múködési költségekre és az innovációs kultúrára adott pontértékek két felvétel közötti dinamikus növekedése.

A teljes minta legalacsonyabb pontértékét Észak-Alföldön találjuk a nemzetközi kapcsolatokra $(2,58)$, míg a legmagasabbat $(4,5)$ Nyugat-Dunántúlon a múködési költségekre.

Ellentmondva hipotézisünknek, mindössze egy-egy kiugróan magas, illetve alacsony pontérték fordult elő az egyes régiók esetében, és egyik várt tényező kapcsán sem figyelhetünk meg területileg összefüggő, régióhatárokon átívelő különbségeket. Magyarázatként szolgálhat erre Lengyel-Varga (2018) tanulmánya, mely szerint az egyes régiókon belül is nagyon eltérő jegyeket mutató megyetípusok helyezkednek el. Említett szerzôk által definiált öt megyetípus (centrum, feldolgozóipari külföldimúködőtőke-befektetések, újraiparosodó, tudásközpont, rurális) közül legalább kettő, több esetben (Észak-Alföldön és Dél-Alföldön) akár három különböző típus jellemzi az egyes régiókat.

Negyedik hipotézisünk az új ismérvként figyelembe vett ágazati megoszláshoz kapcsolódott. Arra számítottunk, hogy míg a 2004/2005. évi kutatásunkban kiemelkedő regionális elérhetőség a szolgáltató szektor válaszadói számára 2016/2017-ben kevésbé lényeges, addig a felvevőpiac éppen esetükben fontosabb, szemben az ipari és agrárvállalkozásokkal. A többi tényezô esetében nem vártunk számottevő szektorközi különbségeket.

A felvevőpiacnál csakugyan kimutatható bizonyos felértékelődés a szolgáltató szektorban, ezzel szemben a regionális elérhetőség a szolgáltatások területén semmivel sem kevésbé fontos, mint a másik két szektor számára (3. táblázat). Az üzleti szolgáltatások jelentőségét a mezőgazdaságban tevékenykedők valamelyest leértékelik, a tényezók többsége viszont egyáltalán nem mutat szektorspecifikus jegyeket. Kapott eredményeink tükrében hipotézisünk csak részben nyert megerősítést.

Területi Statisztika, 2021, 61(1): 79-104; DOI: 10.15196/TS610104 
A telephelyi tényezők szektorális pontértékei

a magyar mikro- és kisvállalkozások megkérdezése alapján, 2016/2017

Sectoral disparities of the location factors, based on the responses of surveyed Hungarian micro- and small businesses, 2016/2017

\begin{tabular}{l|c|c|c}
\hline \multicolumn{1}{c|}{ Tényező } & Mezőgazdaság & Ipar & $\begin{array}{c}\text { Szolgáltatás, } \\
\text { kereskedelem }\end{array}$ \\
\hline Gazdasági szerkezet & 3,94 & 4,01 & 3,83 \\
Innovációs kultúra & 2,86 & 2,87 & 3,04 \\
Regionális elérhetőség & 3,83 & 4,14 & 4,23 \\
Működési költségek & 4,0 & 4,29 & 4,29 \\
Településpolitika & 3,66 & 3,76 & 3,61 \\
Környezeti minőség & 3,4 & 3,36 & 3,55 \\
Közintézmények & 3,29 & 3,38 & 3,52 \\
Üzleti szolgáltatások & 3,26 & 3,69 & 3,77 \\
Munkaeró & 3,74 & 4,03 & 3,87 \\
Felvevőpiac & 3,37 & 3,88 & 4,15 \\
Demográfia-társadalom & 3,09 & 3,11 & 3,4 \\
Nemzetközi kapcsolatok & 2,83 & 2,78 & 2,93
\end{tabular}

Megjegyzés: a megkérdezett vállalkozók és vállalatvezetők az egyes telephelyi tényezőket ötfokozatú skálán értékelték.

Forrás: a szerzők 2016/2017. évi kutatása.

\section{Országos és regionális telephelyi sorrendek (a települések telephelyi vonzerejének megítélése)}

Kérdőíves adatfelvételünk második kérdése során arra kértük a vállalkozások vezetőit, hogy saját tapasztalatuk tükrében sorolják fel a leginkább sikeresnek gondolt magyarországi településeket, és az általunk megadott 12 telephelyi tényező segítségével indokolják is döntésüket. (Mivel Budapest gazdasági értelemben (is) külön kategóriát képvisel a hazai városhálózatban, ezért a fővárost nem szerepeltettük a kutatás ezen részében.)

Mivel 2004/2005. évi kutatási eredményeink kizárólag közép- és nagyvárosokat nevesítettek a leginkább sikeresnek tartott telephelyek között (Koltai 2006, 2007, 2014), valamint ezek gazdasági növekedése közismerten dinamikusabb, mint a kisvárosoké vagy a falvaké, ötödik hipotézisként nagyvárosokat, elsősorban Győrt, Székesfehérvárt, valamint Sopront vártuk az élmezőnybe, és Kecskemét két felvétel közötti jelentősebb felértékelődését prognosztizáltuk.

2016/2017. évi adataink szerint (4. táblázat) Gyôr kiemelkedik a vidéki települések sorából, melyet Debrecen és Székesfehérvár követ. Győr már a 2004/2005. évi adatfelvétel során a válaszok közel 62\%-ában szerepelt (Koltai 2006, 2007), és ez a 
gyakoriság 2016/2017-ben 70\% felettire emelkedett. Debrecen ennél is jelentősebb mértékben, közel másfélszeresére növelte azon válaszadók számát, akik sikeres telephelyként tekintenek a városra, Székesfehérvár említésszáma viszont 6,7\%-kal visszaesett. Szeged alig lemaradva került a negyedik helyre, megelőzve Kecskemétet, Pécset és Sopront. Az alföldi városokat 2004/2005-höz képest kedvezőbben értékelték a megkérdezett vállalkozások. (Kecskemét esetében 2,5-, Szeged esetében 1,5szeres a növekedés.) Pécs említése 9,8\%-kal nőtt, míg a Soproné pedig 21\%-kal csökkent. Jelentősebb lemaradással Szombathely következik (-30,0\%), majd Nyíregyháza $(-2,4 \%)$, Miskolc $(-12,9 \%)$ és Veszprém $(-14,3 \%)$. A listát az 5\%-os említési küszöböt meghaladó települési kör egyetlen új szereplője, Budaörs (+33,3\%) zárja. (Utóbbi a város helyi foglalkoztatási szerepkörének elmúlt évekbeli kedvező irányú változásával is magyarázható [Kiss-Szalkai 2014, Pénzes et al. 2014, Pálóczi et al. 2015].) A város kiemelkedő rezilienciaértékére (Drobniak 2017) Sebestyénné Szép és szerzőtársai (2020) hívják fel a figyelmet. A 2004/2005. évi élmezőny tagjai közül Zalaegerszeg és Kaposvár lekerültek a 2016/2017. évi listáról. Mindkét város esetén hozzávetőlegesen megfeleződött $(-43,1$, illetve $-52,8 \%)$ azon válaszadók száma, akik 2004/2005-höz képest sikeres telephelyként tekintettek rájuk. (Kaposvár említése a dél-dunántúli rangsorban is jelentôs pozícióvesztést mutat. A régió térszerkezetét és strukturális sajátosságait részletesen elemzi Máté (2017), valamint közel két évtizedes tendenciák kimutatására nyilik lehetőség Kozma (1998) magyarországi települések gazdasági alkalmasságát elemző kutatása tükrében. Győr már ekkor az első helyen szerepelt, 2016/2017. évi kutatásunkban a legjobbra értékelt 12 város közül a nyugati országrészben találhatók mindannyian a 2004/2005. évi élmezőny tagjai voltak, míg Kelet-Magyarország reprezentánsai akkor még rosszabb feltételeket kínáltak a megkérdezett vállalkozások szerint. Magyarországi gazdasági centrumokat értékelő kutatásukban Nagy és Nagy (2008) szintén Győrt nevesítik legerôsebb vidéki központként, Székesfehérvárt és Szombathelyt megelőzve, az élmezőny tagjai szintén megegyeznek a 2004/2005. évi kutatási eredményeinkkel.)

A városok sorrendjében az elmozdulást az egy lakosra jutó megyei GDP változása is alátámasztja. Két adatfelvételünk között a legdinamikusabb növekedést GyőrMoson-Sopron és Bács-Kiskun megyék mutatják, megelőzve a listánkra települést nem delegáló Tolna megyét. A vizsgált időszak legalacsonyabb mutatóival Nógrád, Baranya és Zala megyék rendelkeznek (Lengyel-Varga 2018). Szintén a pozícióváltozások tendenciajellegére hívja fel a figyelmet Csomós (2015) településgazdasági súly alapján képzett rangsorával, kimutatva többek között Budaörs előre lépését vagy éppen Pécs folytatólagos lemaradását.

Területi Statisztika, 2021, 61(1): 79-104; DOI: 10.15196/TS610104 
A telephelyek sorrendje a magyar vállalatok megkérdezése alapján, 2016/2017

Ranking of business locations, based on the responses of surveyed Hungarian businesses, 2016/2017

\begin{tabular}{c|l|c}
\hline Sorrend & \multicolumn{1}{|c|}{ Település } & Említésszám \\
\hline 1. & Győrr & 707 \\
2. & Debrecen & 382 \\
3. & Székesfehérvár & 360 \\
4. & Szeged & 344 \\
5. & Kecskemét & 324 \\
6. & Pécs & 269 \\
7. & Sopron & 235 \\
8. & Szombathely & 108 \\
9. & Nyíregyháza & 81 \\
10. & Miskolc & 81 \\
11. & Veszprém & 66 \\
12. & Budaörs & 64
\end{tabular}

Forrás: a szerzők 2016/2017. évi kutatása.

További sorrend a legalább 2\%-os említési határt elért településeknél: Eger, Tatabánya, Siófok, Zalaegerszeg, Dunaújváros, Szolnok, Érd, Hévíz, Kaposvár, Gödöllő, Esztergom. (Ezen másodlagos vidéki szintnek minősülő településeket tipizálja Csomós (2015) a helyben múködő gazdasági szervezetek pénzügyi adatai alapján, megkülönböztetve azok fővárosi agglomerációs, tradicionális iparközpont, új gazdasági központ vagy idegenforgalmi jellegét.)

Természetesen ezúttal is lehetőségünk nyílt a reprezentativitást biztosító szempontok, így a földrajzi elhelyezkedés, a vállalatméret és az ágazati besorolás szerint további elemzésekre. Ahogy 2004/2005. évi vizsgálatunk során, úgy 2016/2017-ben is egyetlen régióban fordult elő, hogy nem Győrt említették a legversenyképesebb településnek. (2004/2005-ben Észak-Alföldön került a rangsor élére Debrecen.) 2016/2017-ben a közép-dunántúli vállalkozások gondolták ugyanezt Székesfehérvárról, sorrendben Győr, Pécs, Kecskemét, Debrecen, Dunaújváros, Szeged és Veszprém előtt. Miközben a Közép-Dunántúlon az országos listához képest valamivel hátrébb kerültek az alföldi városok, kedvezőbb lett azonban több régióbeli település (Tatabánya, Komárom) pozíciója.

A dél-dunántúli vállalatok 2016/2017-ben már közel kétszer annyian említik Győrt, mint a régiót képviselő, második helyezett Pécset. A sorban harmadik Székesfehérvár lett. Az 5\%-os említés feletti települések rangsorát az országos listán hátrébb szereplő régióbeli városok, Kaposvár, Siófok, Szekszárd és Paks zárják.

Nyugat-Dunántúlon Győrr szintén kiemelkedik, majd Székesfehérvárt alig valamivel lemaradva Szombathely követi. Sopront a saját régióján belül is megelőzi Debrecen, de nem sokkal marad el tőle Kecskemét és Zalaegerszeg említésszáma sem.

Területi Statisztika, 2021, 61(1): 79-104; DOI: 10.15196/TS610104 
A régiós listán megjelenik Nagykanizsa és Szentgotthárd is. (A 2004/2005. évi adatfelvétel során Kecskemét még fel sem került erre a listára.)

Közép-Magyarországon az országos sorrendhez képest valamivel kedvezőbb Szeged, Pécs és Budaörs említésszáma. A régió településeiből az 5\%-os említési gyakorisághoz közel szerepel Gödöllő és Érd, továbbá valamivel ritkábban említve Százhalombatta.

Dél-Alföldön közel hasonlóan ítélik meg Győr, Szeged és Kecskemét helyzetét a vállalkozások. Szemben a 2004/2005. évi kutatással, ezúttal nem került fel a listára a régió harmadik megyeszékhelye, Békéscsaba.

Észak-Alföldön Győr és Debrecen azonos említésszámmal került a rangsor élére, sorrendben a harmadik Nyíregyháza, és az országos listához képest valamivel hátrébb került Szeged. Az 5\%-os említéshatár felett szerepel több régióbeli település, így Jászberény, Szolnok és Kisvárda, valamint Eger.

Észak-Magyarországon az újból kiugró értékkel szereplő Győrt nem a régióközpont Miskolc, hanem Debrecen, majd Sopron, Székesfehérvár, Kecskemét és Szeged követi. Csak utánuk került fel a listára a két megyeszékhely: Miskolc és Eger. A régiós rangsorban megtaláljuk Hatvant és Ózdot, viszont a harmadik megyeszékhely, Salgótarján még itt sem szerepel.

Hipotézisünk teljesült, miszerint nagyvárosok, főként régió- és megyeközpontok kerültek az országos rangsor élére, valamint kivétel nélkül megjelennek a regionális listák második felében az érintett megyék közép- és kisvárosai is. Több alföldi nagyváros (elsősorban Debrecen és Szeged) az általunk vártnál jobb pozíciót kapott. (Érdekes összehasonlításokat tesz lehetővé Egedy [2012] magyar nagyvárosok versenyképességéről készített kutatása. A szerző eredményei kiválóan előre jelzik az általunk mért változások irányát. Győr, Debrecen és Székesfehérvár stabil gazdasági központként történő múködésének részletes elemzését lásd: Rechnitzer et al. 2014, Rechnitzer 2019. Molnár és szerzôtársai [2018] kutatási eredményeikkel szintén megerősítik Debrecen többi régióközpontot meghaladó, dinamikus fejlődését, ahogy Pécs gazdasági növekedésének hanyatlását is. Döbrönte [2018] szintén Debrecent nevesíti a nemzetközi gazdasági áramlásokba potenciálisan bekapcsolódó helyszínként, míg Kecskemét kapcsán Varga és szerzőtársai [2020] a város fiatal, képzett lakosságot vonzó potenciálját emelik ki.)

Külön is érdemes figyelmet fordítani a vállalatméret szerinti listákra. A mikro- és kisvállalatok esetében, mintánkban előforduló arányuk okán nem tapasztalunk különbségeket, ellenben az ennél nagyobb vállalatok esetében már változik a sorrend, és új résztvevőkkel bővül a legsikeresebbnek tartott telephelyek köre. A közép- és nagyvállalatok válaszai alapján Székesfehérvár valamivel közelebb került Győrhöz, Kecskemét említése pedig a teljes mintához és saját 2004/2005. évi említéséhez képest is kedvezőbb lett. Ennek éppen az ellenkezője jellemzi Sopront, melynek említésszáma megfeleződött a két felvétel között. 2016/2017-ben valamivel ritkábban említették Miskolcot, Szombathelyt és Nyíregyházát, és a teljes mintához képest új szereplőnek számít Dunaújváros és Tatabánya. (Hasonló eredményt mutatnak Szabó (2017) nagyvállalatokkal kapcsolatos megyei és regionális szintű vizsgálatai is.)

Területi Statisztika, 2021, 61(1): 79-104; DOI: 10.15196/TS610104 
Az ágazati megoszlás szerinti listák elemezéséből megállapítható, hogy az iparvállalati rangsorban még inkább kiemelkedik Győr, jobb pozíciót ér el Kecskemét, Székesfehérvár és Veszprém, valamint a listában megjelenik Tatabánya, Zalaegerszeg, Dunaújváros és Érd is. Ezzel szemben kedvezőtlenebb Szeged, Pécs és részben Sopron iparvállalati megitélése. Az agrárvállalkozások szerint Székesfehérvár, Debrecen és Kecskemét megítélése előnyösebb, valamint Zalaegerszeg és Szolnok is tagja lett a legsikeresebb tartott telephelyek csoportjának. A mezőgazdasági válaszadók ellenben jelentősen rontottak Sopron, kisebb mértékben Pécs megítélésén. (Mindezt alátámasztja az ipari vállalkozások nagyobb arányú jelenléte Kecskeméten, Székesfehérváron, Győrben és Nyíregyházán, valamint a mezőgazdasági vállalkozások gyakoribb előfordulása Debrecen és Kecskemét gazdasági szerkezetében [Molnár et al. 2018]).

\section{Komplex mutatószám szerinti telephelyi sorrend}

Kutatásunk két korábbi, külön-külön elemzett témakörét (telephelyi tényezők értékelése, ezek tükrében az egyes városok megitélése) komplex módon is vizsgáltuk. Érdekes összevetésekre nyililk lehetőség, amennyiben választ keresünk arra a kérdésre, hogy milyen indokok állnak az egyes városok sikeres telephelyi megítélésének hátterében, és egyben egymáshoz képest is értékeljük a leggyakrabban említett településeket. Ehhez a városok sikerességének jellemzésére adott válaszokat súlyoztuk a tényezők pontértékeivel (1. ábra), ezáltal egy olyan rangsort kaptunk (5. táblázat), amely egyidejúleg mutatja az egyes telephelyi tényezők eltérő jelentőségét, valamint a részletesen vizsgált városok különbségeit.

5. táblázat

A telephelyek komplex mutatószám szerinti sorrendje, 2016/2017

Ranking of business locations according to a complex indicator, 2016/2017

\begin{tabular}{c|l|c}
\hline $\begin{array}{c}\text { Sor- } \\
\text { rend }\end{array}$ & \multicolumn{1}{|c|}{ Település } & Súlyozott pontérték \\
\hline 1. & Györ & 16716 \\
2. & Székesfehérvár & 7286 \\
3. & Debrecen & 6897 \\
4. & Szeged & 6152 \\
5. & Kecskemét & 5936 \\
6. & Pécs & 4649 \\
7. & Sopron & 4628 \\
8. & Szombathely & 1900 \\
9. & Nyíregyháza & 1389 \\
10. & Budaörs & 1315 \\
11. & Veszprém & 1285 \\
12. & Miskolc & 1137
\end{tabular}

Forrás: a szerzők 2016/2017. évi kutatása.

Területi Statisztika, 2021, 61(1): 79-104; DOI: 10.15196/TS610104 
Győr ezúttal is kimagaslik a vidéki városok köréből, 2004/2005. évi rangsorunkhoz (4. táblázat) képest helyet cserélt Székesfehérvár és Debrecen, Sopron pedig felzárkózott Pécshez. Budaörs látványosan javítva pozícióján nemcsak Miskolcot, de Veszprémet is megelőzi. Az említett változásokat az egy válaszadóra jutó súlyozott átlagérték magyarázza, mely az egyes városok esetében jelentős mértékben különbözik (6. táblázat).

A telephelyek súlyozott átlagértéke, 2016/2017

6. táblázat

Weighted average of business locations, 2016/2017

\begin{tabular}{c|l|c}
\hline $\begin{array}{c}\text { Sor- } \\
\text { rend }\end{array}$ & \multicolumn{1}{|c|}{ Település } & Súlyozott átlagérték \\
\hline 1. & Györ & 23,64 \\
2. & Budaörs & 20,55 \\
3. & Székesfehérvár & 20,24 \\
4. & Sopron & 19,69 \\
5. & Veszprém & 19,47 \\
6. & Kecskemét & 18,32 \\
7. & Debrecen & 18,05 \\
8. & Szeged & 17,88 \\
9. & Szombathely & 17,59 \\
10. & Pécs & 17,28 \\
11. & Nyíregyháza & 17,15 \\
12. & Miskolc & 14,04
\end{tabular}

Forrás: a szerzők 2016/2017. évi kutatása.

Győr kiemelkedő megítélését mutatja, hogy bár több mint 700 válaszadó említi a várost valamilyen okból sikeresnek, az egy válaszadóra jutó pontérték is esetében a legmagasabb. A városra nem egyszerúen sok vállalat tekint pozitívan, de mindezt nagyszámú és főleg magasra értékelt telephelyi tényező alapján teszi. Budaörs szintén annak köszönheti kedvező pozícióját, hogy a várost sikeres telephelynek tekintő vállalkozások mindezt számukra fontos tényezókkel magyarázzák. Hasonló okok állnak Sopron és Veszprém előkelő pozíciója mögött is, míg ezzel éppen ellentétes előjelú a változás Debrecen, Szeged, Pécs és Miskolc esetében, ahol a válaszadók kevesebb és egyben kevésbé fontos tényezőkkel indokolják a települések sikerességét. (Hasonló megállapításra jut Lux [2013] három nagyvárosi térséget, Pécset, Miskolcot és Győrt elemző kutatásában.)

\section{Összegzés}

Az általunk elemzett telephelyi tényezők közül a múködési helyszín kijelölésében 2004/2005 és 2016/2017 között az átlagosnál nagyobb mértékben nőtt a településpolitikának, a múködési költségeknek, a munkaerőnek, az innovációs kultúrának és a

Területi Statisztika, 2021, 61(1): 79-104; DOI: 10.15196/TS610104 
környezeti minőségnek a magyarázó ereje. Amellett, hogy a magyar vállalkozások költségérzékenyebbé váltak, egyidejűleg fontosabbá is vált számukra a munkaerő megléte, ami egyértelmúen visszavezethető a munkaképes korúak számbeli csökkenésére és a vizsgált időszakban szűkült kvalifikált munkaerő-kínálatra. Közép- és nagyvállalati körben valamivel meghatározóbb az innovációs kultúra magyarázó ereje, még fontosabbak a múködési költségek és a munkaerő, azonban a vállalatméret növekedésével párhuzamosan veszít jelentőségéből a felvevőpiac és a környezeti minőség magyarázó szerepe. A területi versenyképesség erős hierarchikus meghatározottsága okán közép- és nagyvárosaink vonzása részben ellensúlyozhatja kedvezőtlen földrajzi fekvésüket is, amit jól mutat, hogy nagyvárosok, főként régió- és megyeközpontok kerültek országos és regionális telephelyi rangsoraink élére. Győr kutatásunk minden dimenziójában kiemelkedik a vidéki települések sorából, köszönhetően nagyszámú és egyben magasra értékelt telephelyi tényezőinek. A város és tágabb környezete azon térségek közé tartozik, amelyek a feldolgozóipari külföldimúködőtőke-befektetéseknek köszönhetően a magyar gazdasági növekedés egyértelmű letéteményesei. Pécs, Sopron és Székesfehérvár valamelyest rontott 2004/2005. évi pozíciójához képest, az alföldi városokat (Debrecen, Szeged, Kecskemét) viszont 2016/2017-ben kedvezőbben értékelték a megkérdezett vállalkozások.

A magyar települések telephelyi sikerességének magyarázatai között felértékelődőben vannak gazdasági adottságaik, földrajzi elhelyezkedésük, megközelíthetőségük, infrastrukturális ellátottságuk, humán erőforrásaik képzettsége és helyi fejlesztéspolitikai aktivitásuk. A gazdasági növekedés mögöttes tényezőinek alaposabb vizsgálatából megállapíthatjuk, hogy az innovációvezérelt, tudásalapú fejlődés háttérfeltételei ( $\mathrm{K}+\mathrm{F}-$ kiadások, kutatók és felsőfokú végzettségúek aránya, felsőoktatásban részt vevők száma stb.) még kevéssé meghatározóak napjaink Magyarországán. Ettől függetlenül a hazai településeknek ki kell jelölniük azt az elsősorban alulról szerveződő, térségi specializáción és endogén erőforrásokon alapuló fejlesztési stratégiát, mellyel hosszú távon biztosíthatóvá válik sikeres múködésük. Mivel a magyarországi városok a fôváros kivételével funkcionálisan gyengék és elmaradnak az elégséges méretgazdasági kritériumoktól, mindezt másokkal kooperálva, fejlesztő együttműködések keretében célszerű megtenniük.

\section{IRODALOM}

AlpeK, B. L.-TÉsits, R.-HovÁnYI, G. (2018): Spatial inequalities of disadvantage accumulation and their impact on employability in Hungary Regional Statistics 8 (1): 96-119. https://doi.org/10.15196/RS080104

BAKOS, N.-HidAs, Zs.-KEZÁN, A. (2011): Területi különbségek Magyarországon. A főbb társadalmi és gazdasági folyamatok az ezredforduló után Területi Statisztika (51) 4: $335-357$.

BARTA, GY. (2000): A külföldi működő tőke szerepe a magyar ipar duális struktúrájának és regionális differenciálódásának kialakulásában. In: HORVÁTH, GY.-RECHNITZER,

Területi Statisztika, 2021, 61(1): 79-104; DOI: 10.15196/TS610104 
J. (szerk.): Magyarország területi szerkežete és folyamatai az ezredfordulón pp. 265-281., MTA RKK, Pécs.

CAMAgni, R. (2008): Regional competitiveness. Towards a concept of territorial capital. In: Capello, R.-Camagni, R. P.-Chizzolini, B.-Fratesi, U. (eds.): Modelling regional scenarios for enlarged Europe pp. 33-46., Springer Verlag, Heidelberg. https://doi.org/10.1007/978-3-540-74737-6_3

CAmagni, R. (2009): Territorial capital and regional development. In: CAPELLO, R.NiJKAMP, P. (eds.): Handbook of regional growth and development theories pp. 118-132., Edward Elgar, Cheltenham.

Caniels, M. C. J.-Romijn, H. A. (2006): Localised knowledge spillovers: The key to innovativeness in industrial clusters? In: COOKE, P.-PiccalugA, A. (eds.): Regional development in the knowledge economy pp. 22-42., Routledge, London, New York.

Csomós, GY. (2015): The ranking of cities as centres of the Hungarian economy, 1992-2012 Regional Statistics (5) 1: 66-85. https://doi.org/10.15196/RS05104

DÖBRÖNTE, K. (2018): A közép-európai városok pozíciója a magas szintű üzleti szolgáltatók lokációs döntéseiben Területi Statisztike (58) 2: 200-219. https://doi.org/10.15196/TS580204

DrobniaK, A. (2017): Economic resilience and hybridization of development - A case of the Central European Regions Regional Statistics 7 (1): 43-62. https://doi.org/10.15196/RS07103

EGEDY, T. (2012): A gazdasági válság hatása a nagyvárosok versenyképességére Magyarországon Földrajzi Közlemények (136) 4: 420-438.

ENYEDI, GY. (1993): Társadalmi-területi egyenlőtlenségek és területi politika Magyarországon. In: ENYEDI, GY. (szerk.): Társadalmi-területi egyenlötlenségek Magyarországon pp. 9-21., KJK, Budapest.

ENYEDI, GY. (1996): Regionális folyamatok Magyarországon az átmenet időszakában Hilscher Rezső Szociálpolitikai Egyesület, Budapest.

ENYEDI, GY. (2012): Városi világ Akadémia Kiadó, Budapest.

HARCSA, I. (2015): A területi fejlettség és egyenlőtlenségek lehetséges értelmezései - kritikai értékelés és kutatási eredmények II. Statisz̨tikai Szemle (93) 6: 521-551.

HruBI, L. (2000): A gazdasági térszerkezet változásai Magyarországon. In: HorVÁTH, GY.RECHNITZER, J. (szerk.): Magyarország területi szerkęete és folyamatai az ezredfordulón pp. 237-264., MTA RKK, Pécs.

JÓNA, GY.-HAJNAL, B. (2014): A magyarországi kistérségek területi tőkéjének alakulása Területi Statiştike 54 (2): 99-118.

JózSA, V. (2017): A vállalati beágyazódás Comitatus (27) 1: 78-85.

KISS, É. (2010): Az ipar és a közlekedés kapcsolatrendszerének elméleti kérdései. In: KISS, É. (szerk.): Területi szerkezetváltás a magyar iparban 1989 után pp. 40-55., Dialóg Campus, Pécs-Budapest.

KISS, J. P.-SzALKAI, G. (2014): A foglalkoztatás területi koncentrációjának változásai Magyarországon a népszámlálások ingázási adatai alapján, 1990-2011 Területi Statisztika (54) 5: 415-447.

KOLTAI, Z. (2006): A magyar lakosság és vállalati szféra lakó-, illetve telephelyválasztásának szempontjai Területi Statisztika (46) 3: 240-254.

Területi Statisztika, 2021, 61(1): 79-104; DOI: 10.15196/TS610104 
KOLTAI, Z. (2007): A magyarországi városok versenyképességének vállalati megítélése Tér és Társadalom (21) 2: 23-42. https://doi.org/10.17649/TET.21.2.1106

KOLTAI, Z. (2014): Sikeres és versenyképes városok, Piackutatás a magyar települések körében PTE FEEK, Pécs.

KOvÁCS, Sz.-LuX, G.-PÁGER, B. (2017): A középvállalatok szerepe a feldolgozóiparban: egy magyarországi kutatás első eredményei Területi Statisz̧tika (57) 1: 52-75. https://doi.org/10.15196/TS570103

KőszEgFalvi, Gy. (2020): A magyarországi településrendszer strukturális változásának sajátos vonásai Területi Statiştikea 60 (1): 76-106. https://doi.org/10.15196/TS600107

KozMA, G. (1998): A gazdasági élet szereplőinek térbeli preferenciái Falu V áros Régió (5) 9: 7-14.

KRUGMAN, P. (1993): First nature, second nature, and metropolitan location Journal of Regional Science (33) 2: 129-144. https://doi.org/10.1111/j.1467-9787.1993.tb00217.x

Krugman, P. (1994): Competitiveness: a dangerous obsession Foreign Affairs (73) 2: 28-44. https://doi.org/10.2307/20045917

KRugman, P. (1998): Space: The final frontier Journal of Economics Perspectives (12) 2: 161-174. https://doi.org/10.1257/jep.12.2.161

LENGyeL, I. (2003): Verseny és területi fejlódés: Térségek versenyképessége Magyarországon JATEPress, Szeged.

LENGYEL, I. (2010): Regionális gazdaságfejlesztés. Versenyképesség, klaszterek és alulról szervezódó stratégiák Akadémiai Kiadó, Budapest.

LENGYEL, I.-RECHNITZER, J. (2000): A városok versenyképességéről. In: HoRVÁTH, GY.RECHNITZER, J. (szerk.): Magyarország területi szerkez̨ete és folyamatai az ezredfordulón pp. 130-152., MTA RKK, Pécs.

LENGYeL, I.-REChNitZeR, J. (2004): Regionális gazdaságtan Dialóg Campus, Budapest-Pécs.

LENGYEL, I. -VARGA, A. (2018): A magyar gazdasági növekedés térbeli korlátai - helyzetkép és alapvető dilemmák Közgazdasági Szemle (65) 5: 499-524. https://doi.org/10.18414/KSZ.2018.5.499

LuKÁCS, P. (2020): Az urbanizáció és a lakosság kulturális színvonalának összefüggései az alföldi városokban Területi Statisztike (60) 1: 50-75. https://doi.org/10.15196/TS600106

LuX, G. (2013): Kritikus tömeg alatt: a fejlesztési együttműködés lehetőségei a kisebb nagyvárosokban Tér és Társadalom (27) 4: 52-74. https://doi.org/10.17649/TET.27.4.2512

MÁTÉ, É. (2017): Perforált régiók? - Izolálódó térségek a Dél-Dunántúlon Földrajzi Közllemények (141) 2: 164-178.

MOLNÁR, E.-DÉZSI, GY.-LENGYEL, I. M.-KOZMA, G. (2018): Vidéki nagyvárosaink gazdaságának összehasonlító elemzése Területi Statisztika (58) 6: 610-637. https://doi.org/10.15196/TS580604

NAgy, E.-NAgy, G. (2008): A városok gazdasági potenciálja Falu Város Régió (15) 3: 32-42.

NAGY, G. (2010): A centrumok és erőterek változásai a világgazdaságban. In: MÉSZÁROS, R. (szerk.): A globális gazdaság földrajzi dimenziói pp. 172-198., Akadémiai Kiadó, Budapest.

Nemes Nagy, J. (1996): Centrumok és perifériák a piacgazdasági átmenetben Földrajzi közlemények (120) 1: 31-48.

Területi Statisztika, 2021, 61(1): 79-104; DOI: 10.15196/TS610104 
Nemes NAGy, J. (1998): Vesztesek - nyertesek - stagnálók. A társadalmi-gazdasági változások regionális dimenziói Társadalmi Szemle (53) 8-9: 5-18.

NeMES NAGy, J. (1999): Elágazó növekedési pályák az ezredvégi Magyarországon. In: NEMES NAGY, J. (szerk.): Helyek, terek, régiók pp. 65-86., Akadémiai Kiadó, Budapest.

Nemes Nagy, J.-RutTKAy, É. (1993): Vállalkozások területi terjedése (1982-1991). In: ENYEDI, GY. (szerk.): Társadalmi-terïleti egyenlötlenségek Magyarországon pp. 127-142., KJK, Budapest.

Nemes Nagy, J.-TAgAI, G. (2009): Területi egyenlőtlenségek, térszerkezeti determinációk Területi Statisztika (49) 2: 152-169.

PÁlóczi, G.-PÉnZES, J.-HurbáneK, P.-HAlás, M. (2015): Attempts to delineate functional regions in Hungary based on commuting data Regional Statistics 6 (1): 23-41. https://doi.org/10.15196/RS06102

PÁTHY, Á. (2017): Types of development paths and the hierarchy of the regional centres of Central and Eastern Europe Regional Statistics 7 (2): 124-147. https://doi.org/10.15196/RS070202

PÉnZes, J.-MolnÁr, E.-PÁLÓCZI, G. (2014): Helyi munkaerô-piaci vonzáskörzetek az ezredforduló utáni Magyarországon Területi Statisztika (54) 5: 474-490.

PÉnZES, J.-KIS, J. P.-DEÁK, A.-APÁTI, N. (2018): Térségi sokszínúség és stabilitás: az iskolázottság települési szintű egyenlőtlenségeinek változása Magyarországon 1990-2011 között Terïleti Statisztika (58) 6: 567-594. https://doi.org/10.15196/TS580602

PIRISI, G.-KISS, B.-MÁTÉ, É. (2016): A kisvárosok szerepe a munkaerő-ingázásban Területi Statisztika (56) 4: 415-437. https://doi.org/10.15196/TS560404

PORTER, M. E. (1996): Competitive advantage, agglomeration economies, and regional policy International Regional Science Review (19) 1-2: 85-94. https://doi.org/10.1177/016001769601900208

PORTER, M. E. (1999): Microeconomics competitiveness: findings from the 1999 executive survey. In: The Global Competitiveness Report pp. 30-53., World Economic Forum, Geneva.

PORTER, M. E. (2000): Location, clusters, and company strategy. In: CLARK, G. L.FELDMAN, M. P.- GERTLER, M. S. (eds.): The Oxford handbook of economic geography pp. 253-274., Oxford University Press, Oxford.

RECHNITZER, J. (1994): Fejez̨etek a regionális gazdaságtan tanulmányozásáboz MTA RKK, GyőrPécs.

RECHNITZER, J. (1998): A privatizáció regionális összefüggései Kulturtrade, Budapest.

RECHNITZER, J. (2019): A hazai nagyvárosok gazdasági szerkezetének néhány sajátosságai. In: SEBESTYÉNnÉ SzÉP, T.-NAGY, Z. (szerk.): Ember - Tér - Idô: Tanulmányok Kocziszkey György tiszteletére pp. 218-228., Bíbor Kiadó, Miskolci Egyetem Gazdaságtudományi Kar, Miskolc.

RECHNITZER, J.-PÁTHY, Á.-BERKES, J. (2014): A magyar városhálózat stabilitása és változása Tér és Társadalom (28) 2: 105-127. https://doi.org/10.17649/TET.28.2.2623

ReChnitzer, J.-Berkes, J.-FILEP, B. (2019): The most important city development initiatives of Hungary Regional Statistics (9) 2: 20-44.

https://doi.org/10.15196/RS090204

Területi Statisztika, 2021, 61(1): 79-104; DOI: 10.15196/TS610104 
ScotT, A. J.-Agnew, J.-SOJA, E. W.-STORPER, M. (2001): Global city-regions. In: SCOTT, A. J. (ed.): Global city-regions. Trends, theory, policy pp. 11-32., Oxford University Press, Oxford.

SCOTT, A. J.-STORPER, M. (2003): Regions, globalization, development Regional Studies (37) 6-7: 579-593. https://doi.org/10.1080/0034340032000108697a

SEBESTYÉNNÉ SZÉP, T.-SZENDI, D.-NAGY, Z.-TÓTH, G. (2020): A gazdasági reziliencia és a városhálózaton belüli centralitás közötti összefüggések vizsgálata Területi Statisztika (60) 3: 352-369. https://doi.org/10.15196/TS600303

STORPER, M. (2000): Globalization, localization, and trade. In: ClARK, G. L.-FELDMAN, M. P.- GERTLER, M. S. (eds.): The Oxford handbook of economic geography pp. 146-165., Oxford University Press, Oxford.

SzABÓ, M. (2017): Spatial distribution of the top 500 companies on regional and county levels in Hungary - a repeated analysis Regional Statistics (7) 2: 148-170. https://doi.org/10.15196/RS070208

SZAKÁLNÉ KANÓ, I.-KAZEMI-SÁNTA, É.-LENGYEL, I. (2017): Territorial distribution of highly educated individuals in Hungary after 1990 Regional Statistics (7) 2: 171-189. https://doi.org/10.15196/RS070209

TAgAi, G.-BERnARD, J.-ŠImon, M.-KoÓs, B. (2018): Two faces of peripherality: labour markets, poverty, and population dynamics in Hungary and Czechia Regional Statistics 8 (2): 19-45. https://doi.org/10.15196/RS080204

TóTH, B. I. (2014): A hazai kistérségek vonzerejének és területi tőkéjének néhány összefüggése Területi Statisqtika 54 (1): 3-18.

VARGA, A. (2002): Johann von Thünen és az „új gazdaságföldrajz” térgazdaságtana. In: BARAncsuk, J.-OroszI, S.-VARGA, A. (szerk.): Tanulmánykötet Zinhober Ferenc professzor emlékére pp. 87-98., PTE KTK, Pécs.

VArga, V.-Teveli-HorvátH, D.-SAlAmin, G. (2020): A fiatal, képzett lakosságot vonzó potenciál a Budapest körüli csapágyvárosokban Területi Statisztika (60) 2: 179-210. https://doi.org/10.15196/TS600204 